\title{
New process of catalytic oxidation of organic pollutants from water in soft conditions in presence of sulfonated cobalt phthalocyanines supported on activated carbon
}

\author{
El Goul .Faten ${ }^{1}$ \\ Seffen .Mongi ${ }^{2}$; \\ 1-Laboratory of chemistry, Preparatory School for the Military Academies, Sousse \\ 4000, Tunisia \\ 2- Laboratory of chemistry, High Institute of Agronomy, Chott Meriem 4042, Sousse, \\ Tunisia
}

\begin{abstract}
In the field of water treatment, catalytic oxidation has been developed around the Fenton reagent (hydrogen peroxide coupled with ferrous iron salt) but this oxidative system has drawbacks. In effect, this system only works in acidic $\mathrm{pH}$. In addition, the Fenton reagent used at room temperature generally offers a partial oxidation of pollutants and is not accompanied by a significant removal of total organic carbon.
\end{abstract}

The WPO process (Wet Peroxide Oxidation) that uses the catalytic activation of peroxide hydrogen at high temperature accelerates the kinetic of degradation reactions. But this method poses problems of cost due to the use of high temperatures reaching $140^{\circ} \mathrm{C}$.

In clean water, the oxygen is found mainly in the processes WAO (Wet Air Oxidation) which generates a huge investment because of high temperature and pressure ( 250 to $320^{\circ} \mathrm{C}$ - 50 to 150 bar). This represents a major drawback in the industry.

The catalytic oxidation reactions in the presence of métallophthalocyanines described in the literature involve $\mathrm{KHSO}_{5}$ or $\mathrm{H}_{2} \mathrm{O}_{2}$ which presents a disadvantage in a field of water depollution. Indeed, for the oxidation of trichlorophenol, adding an organic co-solvent is necessary: The reactions present the inconvenient to be conducted in a mixture acetonitrile / buffer (1 / $3, \mathrm{~V} / \mathrm{V})$ and not in an aqueous medium .Therefore, it appears that finding a method for oxidation catalysis involving transition metals and using oxygen under mild conditions of temperature and pressure is a particularly important challenge.

During this work, we showed that the synthesis of a catalyst: phthaolocyanine cobalt sulfonated fixed on activated carbon is a simple process that takes place at room temperature. The action of these catalysts has been studied in the oxidation of hexanoic acid by oxygen in normal conditions ( $20^{\circ} \mathrm{C}, 1 \mathrm{~atm}$.).

We studied the reaction using two catalysts supported on activated carbon as grains, containing respectively 12 and $50 \mu \mathrm{mol} / \mathrm{g}$ cobalt. We showed that: 
- the acid mineralization increases with the degree of grafting. In all cases, 97\% of hexanoic acid is removed after $6 \mathrm{~h}$.

- the behavior of catalysts has been studied through recycling. The catalyst with the lowest content in cobalt showed an increase of activity during the first four cycles. Such activity is stabilised with apparent values of the fall of total organic carbon (TOC) and chemical demand of oxygen (COD) of about $90 \%$. The increase of cobalt concentration enhances the rate of mineralization (expressed in relation to TOC eliminate d) from $45 \%$ in the first cycle to $62 \%$ at the third cycle.

The loss of cobalt is very low. It is below $0,57 \%$ after six cycles.

We have also tested the catalytic action of this system in the succinic acid oxidation, oxalic acid and trichlorophenol. We obtain a quasi total fall of TOC and COD and an important rate of mineralization.All these consistent results, can validate this catalytic system. Especially since the catalyst is inexpensive.

\section{KEYWORDS}

Water treatment ; catalytic oxidation ; phthalocyanines ; activated carbon ; oxygen.

\section{INTRODUCTION}

In front of the toxicity of industrial discharges which represent a threat for the balance of the ecosystem, the regulations on dumpings and on standards of discharges evolve ceaselessly towards a bigger severity.

So, as soon as it is about organic and toxic or with difficulty biodegradable aqueous organic waste, the processes of oxidation have a place of choice.

In the field of the water treatment, the catalytic oxidation especially developed around the reagent of Fenton [1] but this oxidizing system works only in $\mathrm{pH}$ acid. Besides, the reagent of Fenton used at room temperature allows generally a partial oxidation of pollutants and is not accompanied by an important elimination of the total organic carbon.

The WPO process allows to accelerate the kinetics of degradation reactions. But this process raises problems of cost due to the use of high temperatures reaching $140{ }^{\circ} \mathrm{C}$ [2].

In the cleanup of water, we find dioxygen especially in WAO process (Wet Air Oxidation) [3]. Oxidation in aqueous phase by the molecular oxygen with temperature and pressure raised ( 250 - $320^{\circ} \mathrm{C}-50$ in 150 bars) allows to answer problems posed by the toxic aqueous waste which cannot be treated by biological way. In spite of the process efficiency, the binding conditions of functioning (temperature and pressure raised) engender a heavy investment and constitute a brake in the development of this treatment method .

Phthalocyanine complexes of transition metals are attractive as potential oxidation catalysts because of their rather cheap and facile preparation in a large scale and their chemical and thermal stability.

Metallophthalocyanines are well known as electrocatalysts for oxidation of variety of analytes including chlorophenols [4, 5]. 
All the reactions of catalytic oxidation in presence of metallophthalocyanines described in literature involve $\mathrm{KHSO}_{5}$ or $\mathrm{H}_{2} \mathrm{O}_{2}$ as oxidizing agent and do'nt enter within the framework of water cleanup . The addition of a co - organic solvent in the reactional middle is indispensable; the authors do not work in an aqueous middle but in a mixture acetonitrile / buffer $(1 / 3, \mathrm{~V} / \mathrm{V})$ or in a solution phosphates buffer / ethanol $(80 / 20)$ or in a solution phosphates buffer / acetone 80 / 20 [6, 7, 8].

Conçerning the stability of metallophthalocyanines in the presence of $\mathrm{H}_{2} \mathrm{O}_{2}$ or $\mathrm{KHSO}_{5}$, certain authors are discreet about this stability $[9,10]$ while the others show the fast degradation of catalyst in presence of these oxidizing agents whether it 's in solution or supported [11].

As regards the reactions of oxidation involving the dioxygen as the oxidizer, we find especially in the literature the use of cobalt phthalocyanine supported in oxidation of thiols to disulfures in oil distillates [12, 13].

A phthalocyanine complex with eight triethoxysylil substituents which can be directly anchored to silica without any modification of silica support shows good catalytic activity in epoxidation of olefins by dioxygen in the presence of isobutyraldehyde. The same catalytic system is also active in the oxidation of phenols to biphenols [14].

Thus it seems that to find a catalysis oxidation process involving metallophthalocyanines and using the dioxygen in soft conditions constitutes a particularly important challenge.

\section{Grafting of métallophtalocyanines on activated carbon :}

The activated carbon used as catalyst support should be extremely pur to prevent inhibition of chemical reaction. In particular, the presence of ashes would make a low yield . It should also be mechanically resistant to prevent formation tiny particles through attrition of particles which would generate a loss of material as well as a fall of yield.

Then we have chosen two types of activated carbon used in catalysis, characterised by a good resistance and their rate of very low impurities.

- $\quad$ the activated carbon Acticarbone CECA (grains)

- $\quad$ the activated carbon AC 35 CECA (extruded)

The grafting reaction on activated carbon takes place at an ambient temperature by a simple addition of sulfonated cobalt phthalocyanine CoPcS solution with sufficient concentration to make an aqueous suspension of activated carbon in the presence of $\mathrm{NH} 4 \mathrm{OH}$.

We obtain a black material whose graft rate has been calculated and which be caracterised by IR spectroscopy by diffused reflection.

The graft rate has been calculated through two different manners : by atomic absorption dosing the supported $\mathrm{Co}(\mathrm{II})$ and by UV-visible spectroscopy dosing the quantity of CoPcS getting in the filtrat and into the washing solutions.

The stability of the activated carbon grafted by CoPcS has been studied.

It remains stable for $\mathrm{pH}$ between 2 and 10. In fact, no relargage has been observed by UV visible spectroscopy after 6 - hour agitation in water for $\mathrm{pH}$ between 2 and 10 . 
This synthesis seems to be suitable for an eventual adaptation at an industual level. In fact, the operatory method is simple and the obtained results are correct, the graft rates vary from 1 to 4,5.10-5 mol/g with rates also varying from $60 \%$ to $99 \%$ for the most important grafts.

We have also been able to show the role of $\mathrm{NH}_{4} \mathrm{OH}$. In fact, we realized that the $\mathrm{pH}$ had an important role in the fixation on activated carbon which is optimal for $\mathrm{pH}$ between 8,5 and 10 .

\section{3 catalytic Oxidation of the hexanoic acid:}

These oxidation reactions were carried out in an engine into which we introduce the catalyst (with a concentration of $100 \mathrm{~g} / \mathrm{l}$ ) and $525 \mathrm{ml}$ of water in which we solubilized $182 \mu 1$ of hexanoic acid what corresponds respectively to an initial TOC and an initial COD due to the hexanoic acid of $200 \mathrm{mg} / \mathrm{l}$ and $680 \mathrm{mg} / \mathrm{l}$. All the oxidation reactions have a a duration of 6 hours with a gas flow of $25 \mathrm{l} / \mathrm{h}$ and a gas pressure at the entry of the engine of 0,38 bars. The catalysts were tested in the oxidation of the hexanoic acid by dioxygen.

\section{3-1 Variation of grafting rate:}

Two catalysts grafted on activated carbon Acticarbone (grains) prepared with different grafting rates $(12 \mu \mathrm{mol} / \mathrm{g}$ and $45 \mu \mathrm{mol} / \mathrm{g}$ ), were tested in the hexanoic acid oxidation by oxygen. The results are presented in the following table:

\begin{tabular}{|c|c|c|}
\hline Catalyst & $\begin{array}{c}\text { CoPcS / CA Acticarbone } \\
\text { (grains) (I) }\end{array}$ & $\begin{array}{c}\text { CoPcS / CA Acticarbone (grains) } \\
\text { (II) }\end{array}$ \\
\hline Temperature $\left({ }^{\circ} \mathrm{C}\right)$ & 20 & 20 \\
\hline Grafting rate & $12 \mu \mathrm{mol} / \mathrm{g}$ & $45 \mu \mathrm{mol} / \mathrm{g}$ \\
\hline [catalyst] g/l & 100 & 100 \\
\hline [metal] g/l & 0,07 & 0,3 \\
\hline $\mathrm{pH}_{\mathrm{i}}{ }^{*}$ & 4,13 & 4,52 \\
\hline $\mathrm{TOC}_{\mathrm{i}}(\mathrm{mg} / \mathrm{L})$ & 173 & 206 \\
\hline $\mathrm{COD}_{\mathrm{i}}(\mathrm{mg} / \mathrm{L})$ & 627 & 662 \\
\hline$\Delta \mathrm{TOC}(\mathrm{mg} / \mathrm{L})$ & 116 & 142 \\
\hline$\Delta \mathrm{TOC} \%$ & 67 & 69 \\
\hline$\Delta \mathrm{COD}(\mathrm{mg} / \mathrm{L})$ & 456 & 513 \\
\hline$\Delta \mathrm{COD} \%$ & 73 & 77 \\
\hline $\mathrm{pH}_{\mathrm{f}}$ & 9,41 & 9,47 \\
\hline$\Delta \mathrm{IC}(\mathrm{mg} / \mathrm{L})$ & 30 & 64 \\
\hline $\begin{array}{c}\text { Mineralization rate } \\
\%\end{array}$ & 17 & 45 \\
\hline$[\mathrm{AH}]_{\mathrm{i}} \mathrm{mg} / \mathrm{l}$ & 315 & 335 \\
\hline$[\mathrm{AH}]_{\mathrm{f}} \mathrm{mg} / \mathrm{l}$ & 10 & 10 \\
\hline Eq TOC $(\mathrm{mg} / \mathrm{L})$ & 6 & 6 \\
\hline$\% \mathrm{TOC}_{\mathrm{f}}$ & 11 & 9 \\
\hline$\Delta[\mathrm{AH}] \%$ & 97 & 97 \\
\hline
\end{tabular}


* $\mathrm{pH}_{\mathrm{i}}$ is the $\mathrm{pH}$ of hexanoïc acid solutions without material

Table 1.

Whatever is the grafting rate, the falls of TOC and COD are relatively invariant and respectively of the order of $70 \%$ and $77 \%$. Simultaneously, the disappearance of the hexanoïc acid is almost total in 6 hours (97\%).

We also notice that the rate of mineralization increases with the rate of grafting.

\section{Balance sheet in carbon:}

The balance sheet in carbon is established for both catalysts (with two grafting rates:12 $\mu \mathrm{mol} / \mathrm{g}$ and $45 \mu \mathrm{mol} / \mathrm{g})$

The lack in the carbon balance sheet $=\left[\left(\mathrm{TOC}_{\mathrm{i}}-\mathrm{TOC}_{\mathrm{f}}-\Delta \mathrm{IC}\right) / \mathrm{TOC}_{\mathrm{i}}\right] * 100$.

\begin{tabular}{ccc}
\hline Catalyst & CoPcS / activated carbon (grains & CoPcS / activated carbon (grains \\
\hline Grafting rate $(\mu \mathrm{mol} / \mathrm{g})$ & 12 & 45 \\
$\mathrm{TOC}_{\mathrm{i}}(\mathrm{mg} / \mathrm{L})$ & 173 & 206 \\
$\mathrm{TOC}_{\mathrm{f}}(\mathrm{mg} / \mathrm{L})$ & 57 & 64 \\
$\Delta \mathrm{IC}(\mathrm{mg} / \mathrm{L})$ & 30 & 63 \\
lack in the carbon balance sheet & 50 & 38 \\
\% $\mathrm{COT}_{\mathrm{i}}$ & & \\
\hline
\end{tabular}

Table 2.

The lack in the balance sheet in carbon decreases when the rate of grafting increases. Indeed, more the rate of grafting increases, more the liberation of CO2 is important sign of a more advanced reaction. The lack in the carbon balance sheet is due to organic compounds adsorbed at the end of reaction.

\section{3-2 Effect of the adsorption of organic compounds on the activity of the catalyst with a grafting rate of $12 \mu \mathrm{mol} / \mathrm{g}$ :}


This catalyst is used in six successive oxidation essays to oxidize in every essay during 6 hours, $200 \mathrm{mg} / \mathrm{l}$ of TOC due to the hexanoïc acid.

The catalyst underwent no wash and no drying between the oxidation essays: the catalyst is just filtered and reintroduced in a new solution.

The obtained results are summarized in the table 3

\begin{tabular}{lcccccc}
\hline $\begin{array}{l}\text { Oxidation } \\
\text { essays }\end{array}$ & $1^{\text {st }}$ essay & $2^{\text {nd }}$ essay & $3^{\text {rd }}$ essay & $4^{\text {th }}$ essay & $5^{\text {th }}$ essay & $6^{\text {th }}$ essay \\
\hline Duration & $6 \mathrm{~h}$ & $6 \mathrm{~h}$ & $6 \mathrm{~h}$ & $6 \mathrm{~h}$ & $6 \mathrm{~h}$ & $6 \mathrm{~h}$ \\
[catalyst] g/l & 100 & 100 & 100 & 100 & 100 & 100 \\
[metal] g/l & 0,07 & 0,07 & 0,07 & 0,07 & 0,07 & 0,07 \\
$\mathrm{pH}_{\mathrm{i}}$ & 4,13 & 4,16 & 4,00 & 4,32 & 4,38 & 4,43 \\
$\mathrm{TOC}_{\mathrm{i}}(\mathrm{mg} / \mathrm{L})$ & 173 & 205 & 185 & 184 & 194 & 199 \\
$\mathrm{DOD}_{\mathrm{i}}(\mathrm{mg} / \mathrm{L})$ & 627 & 665 & 656 & 669 & 649 & 659 \\
$\Delta \mathrm{TOC}(\mathrm{mg} / \mathrm{L})$ & 116 & 156 & 143 & 161 & 178 & 179 \\
$\Delta \mathrm{TOC} \%$ & 67 & 76 & 77 & 87 & 91 & 90 \\
$\Delta \mathrm{COD}(\mathrm{mg} / \mathrm{L})$ & 456 & 504 & 551 & 611 & 602 & 602 \\
$\Delta \mathrm{COD} \%$ & 73 & 76 & 84 & 91 & 93 & 91 \\
$\mathrm{pH}$ & 9,41 & 9,18 & 8,87 & 8,39 & 8,36 & 8,27 \\
& & & & & & \\
$\Delta \mathrm{IC}(\mathrm{mg} / \mathrm{L})$ & 30 & 18 & 17 & 57 & 76 & 70 \\
mineralization $_{\mathrm{rate} \%}$ & 17 & 12 & 12 & 35 & 43 & 40 \\
{$[\mathrm{AH}]_{\mathrm{i}} \mathrm{mg} / \mathrm{l}$} & 315 & 314 & 314 & 304 & 329 & 347 \\
{$[\mathrm{AH}]_{\mathrm{f}} \mathrm{mg} / \mathrm{l}$} & 10 & 19 & 29 & 11 & 16 & 22 \\
$\mathrm{Eq} \mathrm{TOC} \mathrm{(mg/L)}$ & 6 & 12 & 18 & 7 & 10 & 14 \\
$\% \mathrm{TOC}$ & 11 & 24 & 43 & 30 & 59 & 72 \\
$\Delta[\mathrm{AH}] \%$ & 97 & 94 & 91 & 96 & 95 & 93 \\
\hline
\end{tabular}

Table 3.

The apparent rate of mineralization, is close to $15 \%$ on the first three essays, passes then to $40 \%$ and this corresponds to a $\mathrm{pH}$ of the reactional medium stabilized at 8,3.

During the dosage of the hexanoïc acid by CIHP, we detected in addition to residual acid new products among which two were identified thanks to:

.their retention time 
.the comparison with stallion compounds

They are the maleic acid: $\mathrm{C}_{4} \mathrm{H}_{4} \mathrm{O}_{4}$ and the malonic acid: $\mathrm{C}_{3} \mathrm{H}_{4} \mathrm{O}_{4}$

\begin{tabular}{|c|c|c|c|c|c|c|c|}
\hline Essay & $\mathrm{TOC}_{\mathrm{f}}$ & $\begin{array}{l}\text { Identified } \\
\text { Products }\end{array}$ & $\begin{array}{c}\text { retention } \\
\text { time(min) }\end{array}$ & c. $(\mathrm{mg} / \mathrm{L})$ & $\begin{array}{c}\text { TOC } \\
\text { equivalent } \\
(\mathrm{mg} / \mathrm{L})\end{array}$ & $\begin{array}{c}\% \\
\mathrm{TOC}_{\mathrm{f}}\end{array}$ & $\begin{array}{c}\sum \mathrm{C} \text { of } \\
\text { identified } \\
\text { products } \\
(\mathrm{mg} / \mathrm{L})\end{array}$ \\
\hline \multirow[t]{4}{*}{1} & 57 & maleïc & 16,47 & 102 & 42 & 74 & \\
\hline & & acid & & & & & 48 \\
\hline & & hexanoïc & 10,90 & 10 & 6 & 11 & \\
\hline & & Acid & & & & & \\
\hline \multirow[t]{4}{*}{2} & 49 & malonic acid & 15,72 & 8 & 3 & 6 & \\
\hline & & maleïc acid & 16,53 & 27 & 11 & 22 & 26 \\
\hline & & $\begin{array}{l}\text { hexanoïc } \\
\text { acid }\end{array}$ & 10,90 & 19 & 12 & 24 & \\
\hline & & malonic acid & 15,73 & 5 & 2 & 4 & \\
\hline \multirow[t]{2}{*}{3} & 42 & maleïc acid & 16,53 & 8 & 3 & 8 & 23 \\
\hline & & $\begin{array}{l}\text { hexanoïc } \\
\text { acid }\end{array}$ & 10,90 & 29 & 18 & 43 & \\
\hline \multirow[t]{2}{*}{4} & 23 & malonic acid & 15,68 & 9 & 3 & 14 & \\
\hline & & $\begin{array}{c}\text { hexanoïc } \\
\text { acid }\end{array}$ & 10,90 & 11 & 7 & 30 & 10 \\
\hline \multirow[t]{2}{*}{5} & 16 & Malonic acid & 15,48 & 10 & 3 & 20 & \\
\hline & & $\begin{array}{c}\text { hexanoïc } \\
\text { acid }\end{array}$ & 10,90 & 16 & 10 & 59 & 13 \\
\hline \multirow[t]{2}{*}{6} & 20 & malonic acid & 15,60 & 7 & 2 & 12 & \\
\hline & & $\begin{array}{c}\text { hexanoïc } \\
\text { acid }\end{array}$ & 10,90 & 22 & 14 & 72 & 16 \\
\hline
\end{tabular}

Table 4.

However, the other peaks, corresponding to not identified products, were detected by CIHP.

The quantity of maleïc acid with regard to the final TOC decreases when the catalyst activity increases according to the oxidation essays and the quantity of malonic acid with regard to the final TOC increases. The hexanoïc acid seems to be transformed into maleïc acid then in malonic acid then in. $\mathrm{CO}_{2}$.

Loss in active agent:

The dissolved cobalt is measured by atomic absorption in the final sample of every essay of recycling: 


\begin{tabular}{ccccccc}
\hline oxidation Essays & $\begin{array}{l}1^{\text {st }} \\
\text { essay }\end{array}$ & $2^{\text {nd }}$ essay & $3^{\text {rd }}$ essay & $4^{\text {th }}$ essay & $5^{\text {th }}$ essay & $6^{\text {th }}$ essay \\
\hline $\begin{array}{c}\text { dissolved Co } \\
(\mathrm{mg} / \mathrm{L})\end{array}$ & 0,04 & $<0,03$ & $<0,03$ & 0,1 & 0,1 & 0,1 \\
$\%$ & 0,057 & $<0,043$ & $<0,043$ & 0,142 & 0,142 & 0,142 \\
\hline
\end{tabular}

Table 5.

We notice that the cobalt relegate in the solution is very low, lower than $0,57 \%$ after six recycling essays.

\section{3-3 Effect of organic compounds adsorption on the catalyst activity with high rate of metallophtalocyanines :}

The catalyst CoPcS 806 fixed to activated carbon Acticarbone CECA (grains) according with a rate of grafting of $45 \mu \mathrm{mol} / \mathrm{g}$ is used in four successive oxidation essays of solutions of 200 mg C / L of hexanoïc acid.

The catalyst underwent no wash and no drying between the various essays of oxidation.

The obtained results are given in the table below:

\begin{tabular}{lcccc}
\hline Oxidation essays & $1^{\text {st }}$ essay & $2^{\text {nd }}$ essay & $3^{\text {th }}$ essay & $4^{\text {th }}$ essay \\
\hline Duration & $6 \mathrm{~h}$ & $6 \mathrm{~h}$ & $6 \mathrm{~h}$ & $6 \mathrm{~h}$ \\
[catalyst] g/l & 100 & 100 & 100 & 100 \\
[metal] g/l & 0,3 & 0,3 & 0,3 & 0,3 \\
$\mathrm{pH}_{\mathrm{i}}{ }^{*}$ & 4,52 & 4,54 & 4,52 & 4,58 \\
$\mathrm{TOC}_{\mathrm{i}}(\mathrm{mg} / \mathrm{L})$ & 206 & 204 & 207 & 196 \\
$\mathrm{COD}_{\mathrm{i}}(\mathrm{mg} / \mathrm{L})$ & 662 & 643 & 670 & 637 \\
$\Delta \mathrm{TOC}(\mathrm{mg} / \mathrm{L})$ & 142 & 185 & 191 & 182 \\
$\Delta \mathrm{TOC} \%$ & 67 & 76 & 77 & 87 \\
$\Delta \mathrm{COD}(\mathrm{mg} / \mathrm{L})$ & 513 & 587 & 652 & 599 \\
$\Delta \mathrm{COD} \%$ & 69 & 90 & 92 & 94 \\
$\mathrm{pH}_{\mathrm{f}}$ & 4,95 & 4,13 & 4,26 & 4,15 \\
$\Delta \mathrm{IC}(\mathrm{mg} / \mathrm{L})$ & 63 & 103 & 119 & 113 \\
mineralization rate $\%$ & 45 & 56 & 62 & 62 \\
{$[\mathrm{AH}]_{\mathrm{i}}(\mathrm{mg} / \mathrm{L})$} & 335 & 322 & 331 & 314 \\
{$[\mathrm{AH}]_{\mathrm{f}}(\mathrm{mg} / \mathrm{L})$} & 10 & 8 & 8 & 8 \\
Eq TOC (mg/L) & 6 & 5 & 5 & 5 \\
& & & &
\end{tabular}




\begin{tabular}{lcccc}
$\%_{\mathrm{CTOC}}$ & 9 & 25 & 31 & 36 \\
$\Delta[\mathrm{AH}] \%$ & 97 & 94 & 98 & 97 \\
\hline$* \mathrm{pH}_{\mathrm{i}}$ is the $\mathrm{pH}$ of hexanoïc acid solutions without material.
\end{tabular}

Table 6.

The activity of the oxidizing system increases during the use of the catalyst. With this catalyst, presenting a grafting rate of $45 \mu \mathrm{mol} / \mathrm{g}$, two oxidation essays of six hours each seem sufficient to produce reproducible results in term of rate of total organic carbon fall and transformation in carbon dioxide against three essays of six hours each for the catalyst presenting a grafting rate of $12 \mu \mathrm{mol} / \mathrm{g}$. By increasing the rate of grafting, we end more quickly in a better activity of the catalyst.

During the dosage of the hexanoïc acid by CIHP, we detected, as previously the maleïc acid $\mathrm{C}_{4} \mathrm{H}_{4} \mathrm{O}_{4}$ and the malonic acid $\mathrm{C}_{3} \mathrm{H}_{4} \mathrm{O}_{4}$ besides the residual hexanoïc acid.

\begin{tabular}{|c|c|c|c|c|c|c|c|}
\hline Essays & $\mathrm{TOC}_{\mathrm{f}}$ & $\begin{array}{l}\text { Identified } \\
\text { Products }\end{array}$ & $\begin{array}{l}\text { Retention } \\
\text { time (min) }\end{array}$ & c. $(\mathrm{mg} / \mathrm{L})$ & $\begin{array}{c}\text { TOC } \\
\text { equivalent } \\
(\mathrm{mg} / \mathrm{L})\end{array}$ & $\begin{array}{c}\% \\
\mathrm{TOC}_{\mathrm{f}}\end{array}$ & $\begin{array}{c}\sum \mathrm{C} \text { of } \\
\text { identified } \\
\text { products } \\
\text { (mg / L) }\end{array}$ \\
\hline \multirow[t]{3}{*}{$1^{\text {st }}$ essay } & 64 & $\begin{array}{l}\text { malonic } \\
\text { acid }\end{array}$ & 15,62 & 16 & 6 & 9 & \multirow[t]{3}{*}{23} \\
\hline & & maleïc acid & 16,43 & 26 & 11 & 17 & \\
\hline & & $\begin{array}{l}\text { hexanoïc } \\
\text { acid }\end{array}$ & 10,90 & 10 & 6 & 9 & \\
\hline \multirow[t]{2}{*}{$2^{\text {nd }}$ essay } & 19 & $\begin{array}{l}\text { malonic } \\
\text { acid }\end{array}$ & 15,67 & 16 & 5 & 27 & \multirow{2}{*}{10} \\
\hline & & $\begin{array}{l}\text { hexanoïc } \\
\text { acid }\end{array}$ & 10,90 & 8 & 5 & 25 & \\
\hline \multirow[t]{2}{*}{$3^{\text {rd }}$ essay } & 16 & $\begin{array}{l}\text { malonic } \\
\text { acid }\end{array}$ & 15,70 & 14 & 5 & 31 & 10 \\
\hline & & $\begin{array}{c}\text { hexanoïc } \\
\text { acid }\end{array}$ & 10,90 & 8 & 5 & 31 & \multirow{3}{*}{8} \\
\hline \multirow[t]{2}{*}{$4^{\text {th }}$ essay } & 14 & $\begin{array}{l}\text { malonic } \\
\text { acid }\end{array}$ & 15,75 & 10 & 3 & 24 & \\
\hline & & $\begin{array}{c}\text { hexanoïc } \\
\text { acid }\end{array}$ & 10,90 & 8 & 5 & 36 & \\
\hline
\end{tabular}

Table 7. 
The quantity of maleïc acid $\left(\mathrm{C}_{4} \mathrm{H}_{4} \mathrm{O}_{4}\right)$ with regard to the final TOC decreases when the activity of the catalyst increases according to the essays of oxidation, while the quantity of malonic acid $\left(\mathrm{C}_{3} \mathrm{H}_{4} \mathrm{O}_{4}\right)$ increases. The hexanoïc acid seems to be transformed into maleïc acid ( C4) then in acid malonic ( $\mathrm{C} 3$ ) then in $\mathrm{CO}_{2}$.

\section{3-4 Variation of the characteristics of the activated carbon:}

The table below summarizes the results obtained with the catalyst supported on the activated carbon (extruded) and the catalyst fixed on the activated carbon (grains) obtained with two different rates of grafting:

\begin{tabular}{lccc}
\hline $\begin{array}{c}\text { activated carbon } \\
\text { type }\end{array}$ & $\begin{array}{c}\text { AC 35 CECA 3 mm } \\
\text { (extruded) }\end{array}$ & $\begin{array}{c}\text { Acticarbone CECA } \\
\text { (grains) }\end{array}$ & $\begin{array}{c}\text { Acticarbone CECA } \\
\text { (grains) }\end{array}$ \\
\hline Catalyst & $\begin{array}{c}\text { Co 806 / activated } \\
\text { carbon (extruded) }\end{array}$ & $\begin{array}{c}\text { Co 806 / activated } \\
\text { carbon } \\
\text { (grains) }\end{array}$ & $\begin{array}{c}\text { Co 806 / activated } \\
\text { carbon } \\
\text { (grains) }\end{array}$ \\
[catalyst] g/l & 100 & 100 & 100 \\
{$[$ metal] g/l } & 0,05 & 0,07 & 0,3 \\
$\mathrm{pH}_{\mathrm{i}}$ & 4,29 & 4,13 & 4,52 \\
$\mathrm{TOC}_{\mathrm{i}}(\mathrm{mg} / \mathrm{L})$ & 191 & 173 & 206 \\
$\mathrm{COD}_{\mathrm{i}}(\mathrm{mg} / \mathrm{L})$ & 697 & 627 & 662 \\
$\Delta \mathrm{TOC}(\mathrm{mg} / \mathrm{L})$ & 188 & 116 & 142 \\
$\Delta \mathrm{TOC} \%$ & 98 & 67 & 67 \\
$\Delta \mathrm{COD}(\mathrm{mg} / \mathrm{L})$ & 688 & 456 & 513 \\
$\Delta \mathrm{COD} \%$ & 99 & 73 & 69 \\
$\mathrm{pH}$ & 8,01 & 9,41 & 9,47 \\
$\Delta \mathrm{IC}(\mathrm{mg} / \mathrm{L})$ & 28 & 30 & 63 \\
mineralization rate & 15 & 17 & 45 \\
$\%$ & & & \\
\hline
\end{tabular}

Table 8.

With the catalyst [Co806 / activated carbon AC 35 CECA (extruded)], we obtain a very important fall of TOC and COD of the order of $98 \%$ while two other catalysts fixed on the activated carbon (grains) lead to a fall of TOC and in OCD of the order of $70 \%$.

The catalyst [Co806 / activated carbon AC 35 CECA (extruded)] seems more active than the catalyst Co 806 / activated carbon Acticarbone CECA (grains) in spite of lower grafting rate.

On the other hand, the rate of mineralization is sharply more important for the catalyst [Co 806 / activated carbon Acticarbone CECA (grains)] in 0,3 \% in Co. 


\section{Validation of the catalyst:}

To validate the catalyst, we applied the same oxidation system to recalcitrant model molecules, others than the hexanoïc acid which are the succinic acid, the oxalic acid and the trichlorophenol.

\section{4-1 Oxidation of the succinic acid $\left(\mathrm{HO}_{2} \mathrm{CCH}_{2} \mathrm{CH}_{2} \mathrm{CO}_{2} \mathrm{H}\right)$ :}

We made the essays of oxidation in the same conditions as with the hexanoïc acid.

The catalyst tested in the oxidation of the succinic acid by the dioxygen is [Co 806 / Activated carbon AC 35CECA (extruded)] obtained with a grafting rate of $0,05 \%$ of Co.

We realized an oxidation test of the succinic acid by the dioxygen in absence of catalyst. We so verified that the succinic acid is inert towards dioxygen.

During the oxidation of the succinic acid by the dioxygen without catalyst, we observe a very light variation of the $\mathrm{pH}$ as well as an unimportant TOC fall (of $8 \%$ ).

In the presence of the catalyst, we observe a net rise of the $\mathrm{pH}$, a very important TOC fall (of $87 \%$ ) and a significant rate of mineralization (expressed with regard to the eliminated TOC) of the order of $30 \%$.

\section{Effect of the adsorption of organic compounds on the activity of the catalyst:}

The catalyst is six times used for six successive oxidation essays to oxidize in every essay during 6h, $200 \mathrm{mg} / \mathrm{l}$ of TOC due to the succinic acid. The catalyst underwent no wash and no drying between the various oxidation essays but just a filtration.

The obtained results appear in the table which follows:

\begin{tabular}{lcccccc}
\hline $\begin{array}{l}\text { oxidation } \\
\text { essays }\end{array}$ & $1^{\text {st }}$ essay & $2^{\text {nd }}$ essay & $3^{\text {rd }}$ essay & $4^{\text {th }}$ essay & $5^{\text {th }}$ essay & $6^{\text {th }}$ essay \\
\hline Duration & $6 \mathrm{~h}$ & $6 \mathrm{~h}$ & $6 \mathrm{~h}$ & $6 \mathrm{~h}$ & $6 \mathrm{~h}$ & $6 \mathrm{~h}$ \\
[catalyst] g / l & 100 & 100 & 100 & 100 & 100 & 100 \\
[metal] g / l & 0,05 & 0,05 & 0,05 & 0,05 & 0,05 & 0,05 \\
$\mathrm{pH}_{\mathrm{i}}$ & 4,8 & 4,8 & 5,0 & 4,7 & 4,7 & 4,8 \\
$\mathrm{TOC}_{\mathrm{i}}(\mathrm{mg} / \mathrm{L})$ & 179 & 161 & 190 & 180 & 165 & 183 \\
$\mathrm{COD}_{\mathrm{i}}(\mathrm{mg} / \mathrm{L})$ & 485 & 471 & 452 & 455 & 485 & 442 \\
$\Delta \mathrm{TOC}(\mathrm{mg} / \mathrm{L})$ & 156 & 142 & 187 & 154 & 141 & 151 \\
$\Delta \mathrm{TOC} \%$ & 87 & 88 & 98 & 86 & 85 & 83 \\
$\Delta \mathrm{COD}(\mathrm{mg} / \mathrm{L})$ & 413 & 407 & 442 & 427 & 429 & 394 \\
$\Delta \mathrm{COD} \%$ & 85 & 86 & 98 & 94 & 88 & 89 \\
$\mathrm{pH}$ & 7,9 & 6,9 & 7,3 & 7,0 & 7,0 & 6,9 \\
$\Delta \mathrm{IC}(\mathrm{mg} / \mathrm{L})$ & 45 & 49 & 39 & 56 & 45 & 66 \\
mineralizatin & 29 & 35 & 21 & 36 & 32 & 43 \\
rate $\%$ & & & & & & 543 \\
{$[\text { AS }]_{\mathrm{i}} \mathrm{mg} / \mathrm{l}$} & 557 & 481 & 546 & 505 & 556 & 72 \\
{$[\text { AS }]_{\mathrm{f}} \mathrm{mg} / \mathrm{l}$} & 58 & 44 & 0 & 62 & 60 & 29 \\
Eq TOC (mg/L) & 23,5 & 17,9 & 0 & 25 & 24 &
\end{tabular}




\begin{tabular}{lcccccc}
$\%$ TOC $_{\mathrm{f}}$ & 100 & 91,2 & 0 & 98 & 100 & 94 \\
$\Delta[\mathrm{AS}] \%$ & 89,6 & 90,8 & 100 & 88 & 88 & 87 \\
\hline
\end{tabular}

Table 9.

During six oxidation essays, the rate of disappearance of the succinic acid is of about $90 \%$. During the essays, we observe a light increase of the apparent rate of mineralization. This mineralization rate is of $29 \%$ in the first oxidation essay, reaches $43 \%$ at the end of $6^{\text {th }}$ essay of recycling.

During the dosage of the succinic acid by CIHP, we detected, as previously, the maleïc acid, $\mathrm{C}_{4} \mathrm{H}_{4} \mathrm{O}_{4}$ and the malonic acid $\mathrm{C}_{3} \mathrm{H}_{4} \mathrm{O}_{4}$ besides the succinic acid, identified thanks to their retention time and compared with stallion compounds.

\begin{tabular}{|c|c|c|c|c|c|c|c|}
\hline Essay & $\mathrm{TOC}_{\mathrm{f}}$ & $\begin{array}{l}\text { identified } \\
\text { Products }\end{array}$ & $\begin{array}{l}\text { retention } \\
\text { time (min) }\end{array}$ & c. $(\mathrm{mg} / \mathrm{L})$ & $\begin{array}{c}\text { TOC } \\
\text { equivalent } \\
(\mathrm{mg} / \mathrm{L})\end{array}$ & $\begin{array}{c}\% \\
\text { TOC }_{f}\end{array}$ & $\begin{array}{c}\sum \mathrm{C} \text { of } \\
\text { identified } \\
\text { products } \\
(\mathrm{mg} / \mathrm{L})\end{array}$ \\
\hline 1 & 23 & $\begin{array}{l}\text { Succinic } \\
\text { acid }\end{array}$ & 17,8 & 58 & 23 & 100 & 23 \\
\hline \multirow[t]{2}{*}{2} & 19 & $\begin{array}{l}\text { malonic } \\
\text { acid }\end{array}$ & 16,0 & 4 & 1 & 8 & \multirow{2}{*}{19} \\
\hline & & $\begin{array}{l}\text { Succinic } \\
\text { acid }\end{array}$ & 17,8 & 44 & 18 & 91 & \\
\hline 3 & 3 & $\begin{array}{l}\text { malonic } \\
\text { acid }\end{array}$ & 16,0 & 28 & 3 & 90 & 3 \\
\hline 4 & 26 & $\begin{array}{l}\text { Succinic } \\
\text { acid }\end{array}$ & 17,8 & 62 & 25 & 98 & 25 \\
\hline 5 & 24 & $\begin{array}{l}\text { Succinic } \\
\text { acid }\end{array}$ & 17,8 & 60 & 24 & 100 & 24 \\
\hline 6 & 32 & $\begin{array}{c}\text { Succinic } \\
\text { acid }\end{array}$ & 17,8 & 72 & 29 & 94 & 29 \\
\hline
\end{tabular}

Table 10.

For six oxidation essays of the succinic acid, in the experimental errors near, the final TOC is equal to the sum in carbon of the identified products. All the products of the reaction are then known. 


\section{4-2 Oxidation of the oxalic acid $\left(\mathrm{HO}_{2} \mathrm{CCO}_{2} \mathrm{H}\right)$}

Having studied the oxidation of the hexanoïc acid (acid in C6) and that the succinic acid (diacid in C4) by the dioxygen in the presence of the catalyst [CoPcS / activated carbon (extruded)] with a cobalt grafting rate of $0,05 \%$, in soft conditions of temperature and pressure, we applied the same oxidation system to a diacid (in C2) considered too refractory: the oxalic acid.

We made the oxidation essays in the same conditions operating as with the hexanoïc acid and the succinic acid.

Two essays were realized in absence and in the presence of the catalyst.

During the not catalytic oxidation of the oxalic acid by the dioxygen, we observe a very light variation of the $\mathrm{pH}$ as well as TOC and OCD falls (respectively of $3 \%$ and $4 \%$ ). The oxalic acid is inert towards the dioxygen.

However, in the presence of the catalyst, we see a net rise of the $\mathrm{pH}$, a quasi total TOC and OCD fall (of $92 \%$ ) and an important rate of mineralization of $55 \%$ from the first essay of oxidation.

In the table which follows, we compare the activity of the catalyst in the first essay of oxidation of the hexanoïc acid, the succinic acid and the oxalic acid in term of TOC, OCD and rate of mineralization (calculated with regard to the eliminated TOC):

\begin{tabular}{lccc}
\hline Oxydised Acid & $\Delta$ TOC $\%$ & $\Delta$ COD \% & mineralization rate\% \\
\hline hexanoïc acid & 98 & 99 & 15 \\
Succinic acid & 87 & 85 & 30 \\
Oxalic acid & 92 & 91 & 55 \\
\hline
\end{tabular}

Table 11.

The fall of total organic carbon and in chemical demand in oxygen is quasi total for the three studied acids. However, the rate of mineralization, calculated with regard to the eliminated TOC, increases sharply when the studied acid possesses fewer atoms of carbon. The ability to react increases when the carbon chain of the acid to be oxidized is shorter.

\section{4-3 Oxidation of trichlorophenol :}

Having made a success in the oxidation of several carboxylic acids (the hexanoïc acid, the succinic acid and the oxalic acid) considered being all as reclcitrant organic molecules, we have been interested in the oxidation of another family of compounds: the trichlorophenol.

The oxidation by the dioxygen was realized in the same conditions operating as precedely in the presence of the catalyst [CoPcS / activated carbon (extruded)] with a cobalt grafting rate of $0,05 \%$ in soft conditions of temperature and pressure. We come to total TOC and COD falls and at an important rate of mineralization of $46 \%$ from the first essay of oxidation. 


\section{CONCLUSIONS}

We showed that the synthesis of catalysts supported on activated carbon is a simple process which is made in the ambient temperature. According to the nature of supports (extruded or grains) the rates of fixation of the sulfonated cobalt phthalocyanine are different.

The activity of these catalysts was studied in the oxidation of the hexanoïc acid by the dioxygen in the normal conditions $\left(20^{\circ} \mathrm{C}, 1 \mathrm{~atm}\right.$.).

In every case, the catalyst is active. We studied the reaction by means of two catalysts, containing respectively 12 and $45 \mu \mathrm{mol} / \mathrm{g}$ of cobalt. We showed that:

- these catalysts are responsible for the acid mineralization which increases with the rate of grafting. In every case, $97 \%$ of the hexanoïc acid disappears at the end of 6 hours but the apparent rate of mineralization, calculated with regard to the eliminated TOC, nearby of $17 \%$ at the beginning of the reaction and about $40 \%$ to the fourth cycle, indicates a lack to the balance sheet in carbon which is attributed to the adsorption of the inorganic carbon on the surface of the catalyst. Indeed the basic $\mathrm{pH}$ of the reactional medium is convenient to the stabilization in solution of the carbon dioxide released in the form of bicarbonate.

- The behavior of catalysts was studied through their recycling. For the catalyst the least rich in cobalt, an increase of activity is observed during the first four cycles. It stabilizes then with apparent values of TOC and COD falls of the order of $90 \%$. The increase of the concentration in cobalt $(45 \mu \mathrm{mol} / \mathrm{g})$ has no significant effect on the TOC and COD falls but increases the rate of mineralization expressed with regard to the eliminated TOC, from $45 \%$ during the first cycle to $62 \%$ in the third.

- The loss in cobalt is very low. It is lower than 0,57 \% after six cycles.

Both catalytic systems were used, it seems that the system on extruded support is more active than the system on activated carbon (grains) with lower concentration of cobalt and it is the one which was used to study the oxidation of the succinic and oxalic acids and of the trichlorophenol. On the other hand, the system on activated carbon (grains) containing 0,3\% of cobalt gives a more important rate of mineralization of the acid.

In the case of the oxidation of the succinic acid, made in the same experimental conditions, we observe a TOC fall of $87 \%$ and a rate of mineralization about $30 \%$. From the first oxidation essay, the succinic acid disappears totally from the middle, with a rate of mineralization (expressed with regard to the TOC eliminated) of $43 \%$.

In the same conditions and with the same catalyst, the oxidation of the oxalic acid is translated by a TOC fall of $92 \%$ and an important rate of mineralization, (expressed with regard to the eliminated TOC) of $55 \%$ from the first cycle. The catalyst is thus particularly effective.

It's the same for the oxidation of the trichlorophenol. The TOC and COD falls are total and the mineralization rate, expressed with regard to the eliminated TOC, of $46 \%$. The ability to react observed on carboxylic acids is verified with the trichlorophenol.

Every these consistent results, very corresponding, allow to validate the catalytic system. Especially since the catalyst is inexpensive. 


\section{REFERENCES}

[1] Edwards, J. O., Curci, R., 1992. Fenton type activation and chemistry of hydroxyl radical Catalytic oxidations with hydrogen peroxide as oxidant. Strukul G. (Ed), Kluwer Academic Publishers, Dordrecht, The Netherland. 97-151.

[2] Striolo, P., Peyrille, B., Reilhac, P., Foussard, J. N., Debellefontaine, H., 1992. Récents progrès en génie des procédés. 6, 173 - 182.

[3] Debellefontaine, H., Foussard, J. N., Besombes-Vailhe, J., Chakchouk, M., 1991. Recents Prog. Genie Procedes., 5, 123.

[4] Khene, S., Lobb, K., Nyokong, T., 2009. Characterization of nickel tetrahydroxy phthalocyanine complexes and the electrocatalytic oxidation of 4-chlorophenol: Correlation of theory with experiments. Inorganica Chimica Acta. 362, 5055-5063.

[5] Kluson, P., Drobek, M., Strasak, T., Krysa, J., Karaskova, M., Rakusan, J., 2007. Sulphonated phthalocyanines as effective oxidation photocatalysts for visible and UV light regions. Journal of Molecular Catalysis. 272, 213-219.

[6] Hadasch, A., Sorokin, A., Rabion, A.,Meunier, B., 1998. Sequential addition of $\mathrm{H}_{2} \mathrm{O}_{2}, \mathrm{pH}$ and solvent effects as key factors in the oxidation of 2, 4, 6-trichlorophenol catalysed by iron tetrasulfophthamlocyanine. New journal of chemistry. 45-51.

[7] Sanchez, M., Hadasch, A., Rabion, A.,Meunier, B., 1999. Oxidation of 2, 4, 6trichlorophenol catalysed by iron phthalocyanines covalently bound to silica. Comptes rendus de l'Académie des sciences, Paris. 241-250.

[8] Meunier, B., 1992. Metalloporphyrins as versatile catalysts for oxidation reactions and oxidative DNA cleavage. Chemical Reviews. 92, 1411-1456.

[9] Sorokin, A., Seris, J. L., Meunier, B., 1995. Efficient oxidative dechlorination and aromatic ring cleavage of chlorinated phenols catalysed by iron sulfophthalocyanine. Science. 268, 1163-1166.

[10] Vesilind, P. A., 1996. Introduction to Environmental Engineering, PWS Publishing Company, Boston.

[11] Zhu, W., Warren Ford, T., 1993. Oxidation of lignin model compounds in water with dioxygen and hydrogen peroxide catalysed by metallphthalocyanines. Journal of Molecular Catalysis. 78, 367-378.

[12] Buck, T., Bohlenn, H., Wöhrle, D., 1993. Influence of substituents and ligands of various cobalt (II) porphyrin derivatives co-ordinately bonded to silica on the oxidation of mercaptan. Journal of Molecular Catalysis. 80, 253-267.

[13] Hardison, L. C., Dowd, E. J., McManus, D., 1992. Method of making a metal phthalocyanine catalyst. US 005126297A Patent. 
Linnaeus ECO-TECH ' 10

Kalmar, Sweden, November 22-24, 2010

[14] Sorokin, A. B., Mangematin, S., Pergrale, C., 2002. Elective oxidation of aromatic compounds with dioxygen and peroxides catalyzed by phthalocyanine supported catalysts. Journal of Molecular Catalysis. 31, 267-281. 